\title{
Ecological globalistics and the paradigm of world civilization development
}

\author{
Antonina Suzdaleva ${ }^{1, *}$ \\ ${ }^{1}$ Moscow State University of Civil Engineering, 26, Yaroslavskoye Shosse, 129337, Moscow, Russia
}

\begin{abstract}
The nature of public perception of global environmental problems and ways to solve them becomes a paradigm for the development of civilization. The lack of resources necessary for the normal life of people has caused the development of a complex of catastrophic processes. Among them, the most important are: water, food and demographic crises, as well as the crisis of biodiversity, which consists in the widespread destruction of areas of the environment suitable for habitat of plants and animals. The real solution to these problems requires two conditions to be met. First, it is the creation of a scientific basis for the development of a global strategy for the preservation of conditions on the planet suitable for the existence of humans and other organisms. Secondly, it is the need to change the paradigm of environmental perception. The global technogenesis of the biosphere inevitably leads to a widespread transformation of natural conditions. All ecosystems are being transformed into natural and technical systems. The preservation of conditions favorable for human life and other biological species in them is possible only on the basis of the creation and inclusion in these systems of technical means that perform regulatory functions. This approach contradicts traditional ecological thinking and requires a transition to a new paradigm, which can be designated as creative.
\end{abstract}

\section{Introduction}

The paradigm of the development of civilization is the general concept of perception of the existing reality, the tendencies of its development and the possibilities of their change, prevailing in the public consciousness [1]. Despite the periodic change in the public consciousness of the basic ideas about the world around us, the structure of this paradigm, as well as the factors of its formation, remain unchanged from ancient times to the present day. It has always been based on a certain set of postulates that are accepted by the minds of most people as a fact of life that does not require proof. On their basis, stereotypes of thinking were formed as ready-made standard algorithms for solving problems facing society. So, in ancient times, the basis of the perception of the world was formed by the postulates, according to which all observed phenomena are a direct or indirect result of the activity of specific deities. The functions and capabilities of each of them were clearly defined. To designate these deities, we use the concept of supernatural forces, but in the minds of people of ancient times, they were quite natural. Members of society with certain knowledge and

\footnotetext{
* Corresponding author: suzdalevaal@yandex.ru
} 
skills (in the modern sense - priests) could influence the development of events within the established limits.

Our contemporaries are convinced that the world around us consists of atoms and molecules. This is precisely belief, not knowledge. The information about the existence of atoms and molecules was taken without proof by the consciousness of the overwhelming majority for granted. We, like our remote ancestors, believe that people who are specially trained for this activity should have the knowledge sufficient to manage the situation. In our time, they are scientists. Undoubtedly, modern scientists' ideas about the world around them are incomparably deeper and more adequate than those of the ancient priests. A similar judgment can be made about their ability to change the existing situation. But in their activities, most modern specialists are also guided by the dominant postulates and stereotypes of thinking.

However, the development of civilization periodically requires a change in outdated paradigms. This process is always complex and is accompanied by the emergence of conflicts not only among specialists, but also in society. The transition to new paradigms of development usually occurs in the form of the opening of "Overton windows" [2]. Initially, a small group of people makes judgments that are in stark contrast to popular belief. This often causes outrage in society. But as a result of the growing inconsistency of the old paradigm with existing realities, these new ideas are gradually spreading in the public consciousness (fig.1).

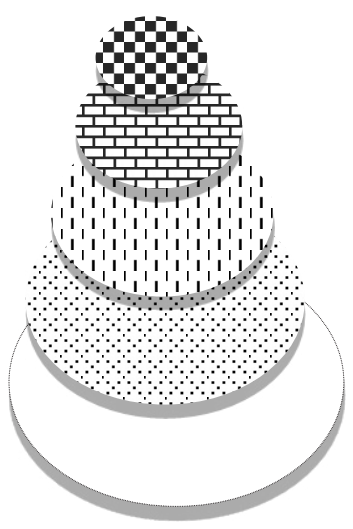

\begin{tabular}{|l|l|l|}
\hline $\begin{array}{c}\text { Stages of the } \\
\text { "Overton } \\
\text { window" } \\
\text { opening }\end{array}$ & $\begin{array}{c}\text { Development } \\
\text { of a new } \\
\text { paradigm }\end{array}$ & \multicolumn{1}{|c|}{$\begin{array}{c}\text { Reaction of the } \\
\text { scientific community }\end{array}$} \\
\hline $\begin{array}{l}\text { from unthinkable } \\
\text { to radical }\end{array}$ & $\begin{array}{l}\text { Putting forward } \\
\text { a new idea }\end{array}$ & $\begin{array}{l}\text { Sharp criticism of a } \\
\text { new idea }\end{array}$ \\
\hline $\begin{array}{l}\text { from radical to } \\
\text { acceptable }\end{array}$ & $\begin{array}{l}\text { Idea as one of } \\
\text { the points of } \\
\text { view }\end{array}$ & $\begin{array}{l}\text { The emergence of } \\
\text { supporters of the idea }\end{array}$ \\
\hline $\begin{array}{l}\text { from acceptable to } \\
\text { reasonable }\end{array}$ & $\begin{array}{l}\text { Widespread } \\
\text { idea }\end{array}$ & $\begin{array}{l}\text { Unbiased discussion of } \\
\text { an idea }\end{array}$ \\
\hline $\begin{array}{l}\text { from reasonable to } \\
\text { popular }\end{array}$ & Dominant idea & $\begin{array}{l}\text { Recognition by the } \\
\text { majority of specialists }\end{array}$ \\
\hline $\begin{array}{l}\text { from popular to } \\
\text { normal }\end{array}$ & New paradigm & $\begin{array}{l}\text { Acceptance as } \\
\text { fundamental }\end{array}$ \\
\hline
\end{tabular}

Fig. 1. Paradigm change occurs in the form of the "Overton window" opening.

The speed at which the paradigm shift occurs is determined by both subjective and objective factors. The main subjective factors are the activity of people putting forward new ideas and their ability to persuade. The most significant objective factor contributing to the change in development paradigms is the real danger of the situation developing without making fundamentally new decisions that run counter to the prevailing postulates and stereotypes of thinking. From this point of view, the need to change the paradigm of the development of world civilization in the field of perception by public consciousness of the role of man in the formation of his environment is becoming more and more urgent [3, 4]. The influence of human activity on the ecological situation on the planet has reached a level at which the priority of the paradigm of the development of civilization becomes the preservation of the conditions for the existence of man as a biological species [5]. The aim of the work is to substantiate the choice of a paradigm that can become the basis for a real solution to this problem. 


\section{Restrictive-prohibitive and creative paradigms}

According to opinions of many people, the widespread deterioration of environmental conditions can be prevented by tightening restrictions and introducing new bans in the field of production activities. This is nothing more than an accepted postulate. There is no evidence that it is possible to solve global environmental problems in this way. On the basis of this postulate, a stereotype of ecological thinking was formed and became widespread, according to which the problem can be solved by isolating the biosphere (areas of natural ecosystems) from the technosphere (areas where production facilities are located). For these reasons, such a paradigm of the development of civilization can be designated as restrictive-prohibitive (fig. 2).

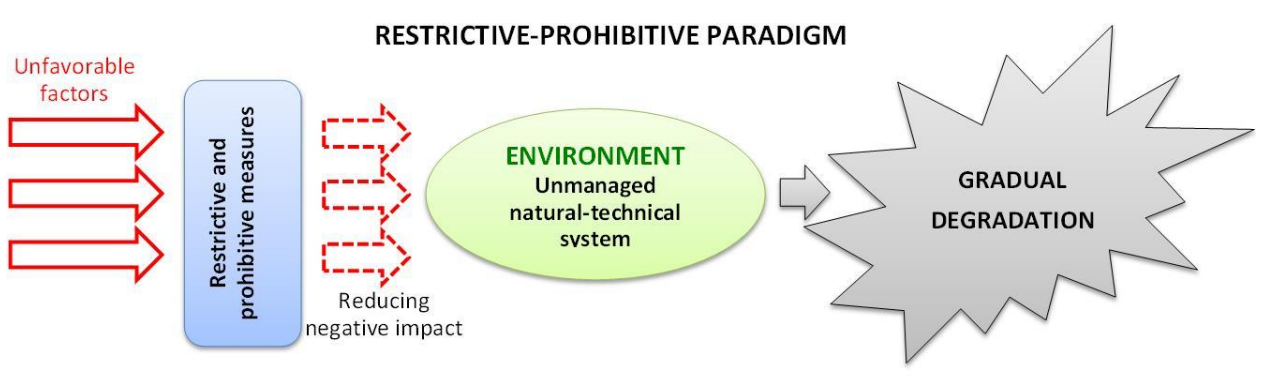

CREATIVE PARADIGM
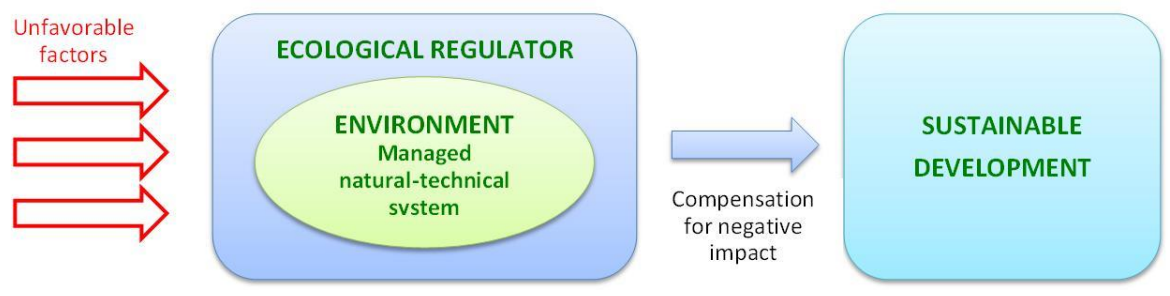

Fig. 2. Ecological paradigms of civilization development (Suzdaleva A.L.www.ntsyst.ru).

However, strengthening control in the areas of environmental protection and rational use of natural resources can only give a temporary result. The incessant growth of population and production volumes is accompanied by an increasing supply of man-made flows of matter and energy into the environment, causing its degradation. Atmospheric and oceanic circulation, as well as global biogeochemical cycles of elements, do not allow localizing the sources of these negative impacts in the long term. Technogenic elements are gradually included in all ecosystems. As a result, they turn into natural and technical systems. In addition, the increase in population determines the continuously growing need for natural resources and for a new space on the planet's surface suitable for human life. Taken together, these phenomena are designated as the process of global technogenesis. Manifestations of technogenesis are very diverse, so it is necessary to classify them. In terms of the scale of the phenomena, the following types of technogenesis can be distinguished: point, local, regional, interregional, and global (fig. 3).

The only real way to change the observed trend in the development of modern civilization is to artificially regulate environmental conditions using technical means. For their designation, the term environmental regulator of a controlled natural-technical system is used. Such a methodological approach inevitably comes into conflict with the dominant stereotype of ecological thinking generated by the restrictive-prohibitive paradigm. At the same time, it finds increasing application in practice. An example is urban ponds with an 
artificial circulation and water conditioning system that acts as an ecological regulator (fig. 4).

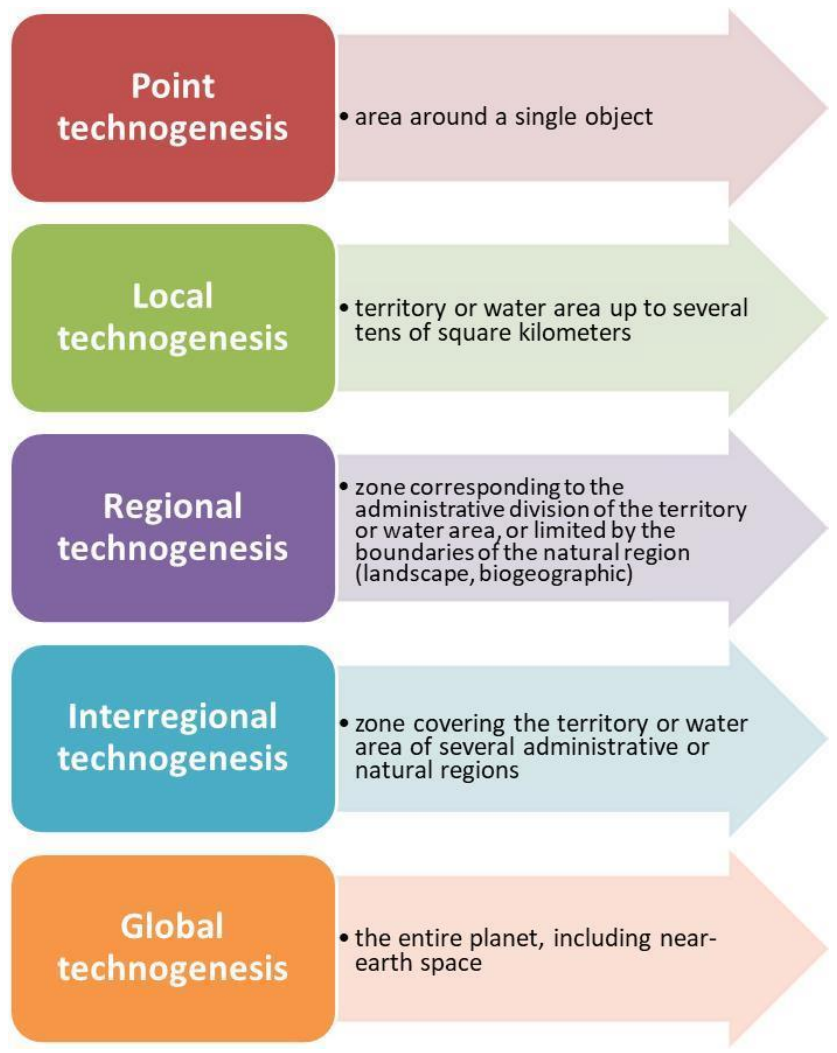

Fig. 3. Classification of types of technogenesis by scale.

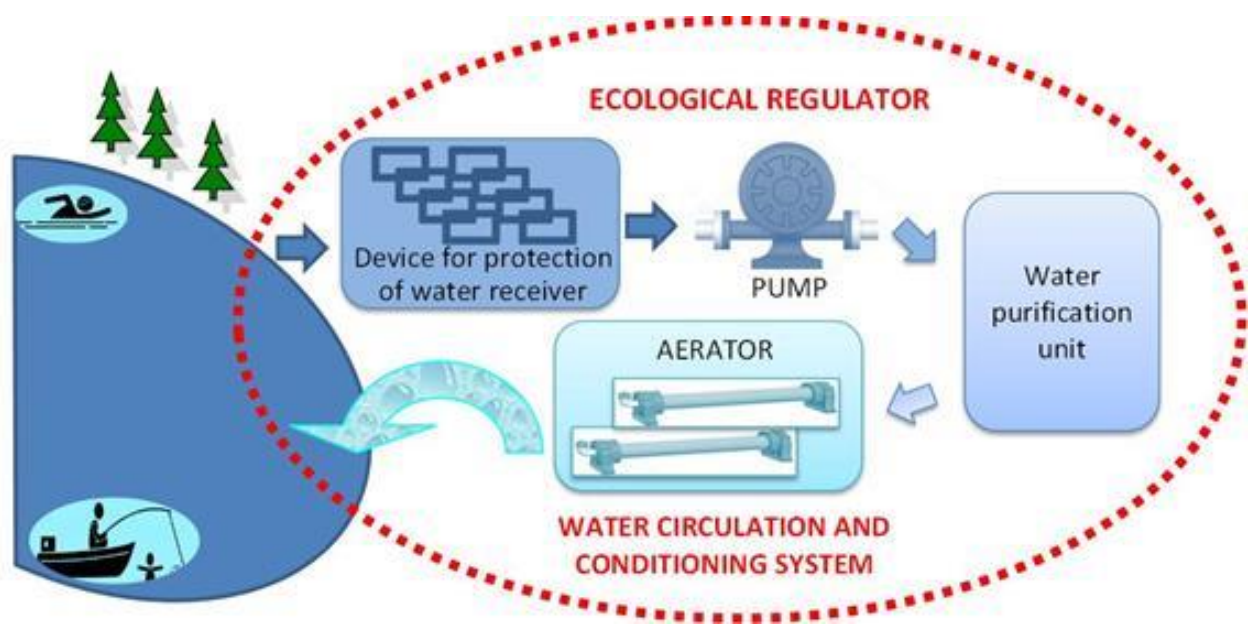

Fig. 4. Managed natural-technical system of the city pond.

Likewise, hydroelectric power plants act as large-scale environmental regulators, which now determine the ecological state of many large river basins. [6]. Paradoxical from this point of view is the status of modern reserves. On the one hand, they were created to preserve 
natural ecosystems. But on the other hand, they are, in fact, controlled natural-technical systems. Favorable ecological conditions in many reserves are preserved thanks to the work of engineering networks and maintenance of their territories using various technical means (fig. 5).

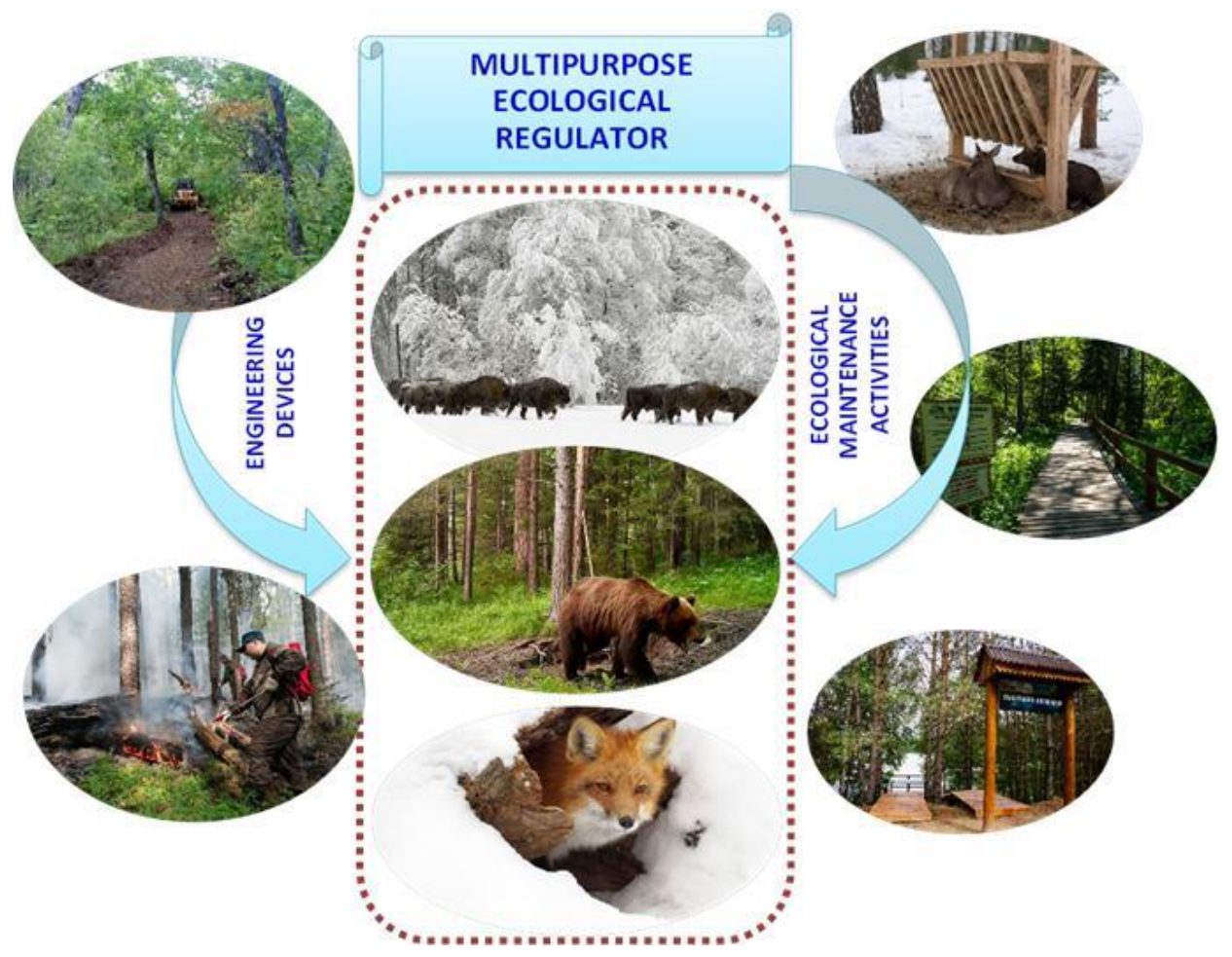

Fig. 5. Managed natural-technical system of the reserve.

The state of the global ecosystem - the biosphere is also increasingly determined by the influence of factors caused by human activity [7]. At the moment, the biosphere is no longer a natural, but a natural-technical system, for which the term biotechnosphere is used [8].

A fundamental change in the process of forming a global ecological situation requires the adoption of a new paradigm, on the basis of which it is possible to develop real ways of solving the problem. The new development paradigm, the end result of which should be the creation of a controlled biotechnosphere, can be designated as creative [9]. In a brief form, a comparative analysis of the described paradigms is presented in Table 1.

Table 1. Paradigms of the development of world civilization.

\begin{tabular}{|c|c|c|}
\hline Characteristic & $\begin{array}{c}\text { Restrictive-prohibitive } \\
\text { paradigm }\end{array}$ & Creative paradigm \\
\hline $\begin{array}{l}\text { Fundamental } \\
\text { postulate }\end{array}$ & $\begin{array}{l}\text { Possibility of separate } \\
\text { coexistence of natural ecosystems } \\
\text { of the technosphere }\end{array}$ & $\begin{array}{l}\text { Replacement of degrading } \\
\text { ecosystems with managed natural } \\
\text { and technical systems }\end{array}$ \\
\hline $\begin{array}{ll}\text { Basic } & \text { thinking } \\
\text { stereotype } & \end{array}$ & $\begin{array}{l}\text { Solving environmental problems } \\
\text { on the basis of prohibitions and } \\
\text { restrictions on activities }\end{array}$ & $\begin{array}{l}\text { Regulation of the state of the } \\
\text { environment by technical means }\end{array}$ \\
\hline Priority target & $\begin{array}{lcr}\begin{array}{l}\text { Conservation } \\
\text { ecosystems }\end{array} & \begin{array}{l}\text { of } \\
\text { outside }\end{array} & \text { natural } \\
\text { technosphere } & & \text { the }\end{array}$ & $\begin{array}{l}\text { Ensuring a favorable ecological } \\
\text { environment on a global scale }\end{array}$ \\
\hline
\end{tabular}




\begin{tabular}{|l|l|l|}
\hline $\begin{array}{l}\text { Implementation } \\
\text { method }\end{array}$ & $\begin{array}{l}\text { Tightening environmental } \\
\text { legislation }\end{array}$ & $\begin{array}{l}\text { Gradual development of a } \\
\text { network of natural and technical } \\
\text { systems }\end{array}$ \\
\hline $\begin{array}{l}\text { The predicted result of } \\
\text { society's acceptance } \\
\text { of this development } \\
\text { paradigm }\end{array}$ & $\begin{array}{l}\text { Gradual degradation of } \\
\text { ecosystems in the process of } \\
\text { global environmental } \\
\text { technogenesis. Development of a } \\
\text { complex of world crises caused } \\
\text { by limited natural resources }\end{array}$ & $\begin{array}{l}\text { Creation of manageable global } \\
\text { natural and technical system - } \\
\text { biotechnosphere, providing } \\
\text { favorable conditions for human } \\
\text { existence and preserving } \\
\text { biodiversity }\end{array}$ \\
\hline
\end{tabular}

\section{Crises in the development of modern civilization and environmental globalistics}

In the most acute form, the inability to prevent the deterioration of the global ecological situation on the basis of the prevailing paradigm manifests itself in the development of a complex of hazardous processes, among which the most significant are:

- global water crisis caused by the shortage of fresh water necessary to meet domestic needs and economic activities;

- global food crisis - a growing shortage of food products, caused by both an increase in the number of humanity and soil degradation, its depletion, as well as a shortage of water resources necessary for agricultural production;

- global demographic crisis, which is based on the growing shortage of space suitable for human life, i.e. environment with favorable ecological conditions;

- global crisis of biodiversity - loss of species as a result of their extermination by humans and destruction of habitats of organisms.

It is unrealistic to fundamentally change these tendencies on the basis of the adoption of international declarations and the provision of humanitarian aid to the regions where the crisis phenomena have become catastrophic. Their further development can be prevented only on the basis of a creative paradigm (fig. 6). 


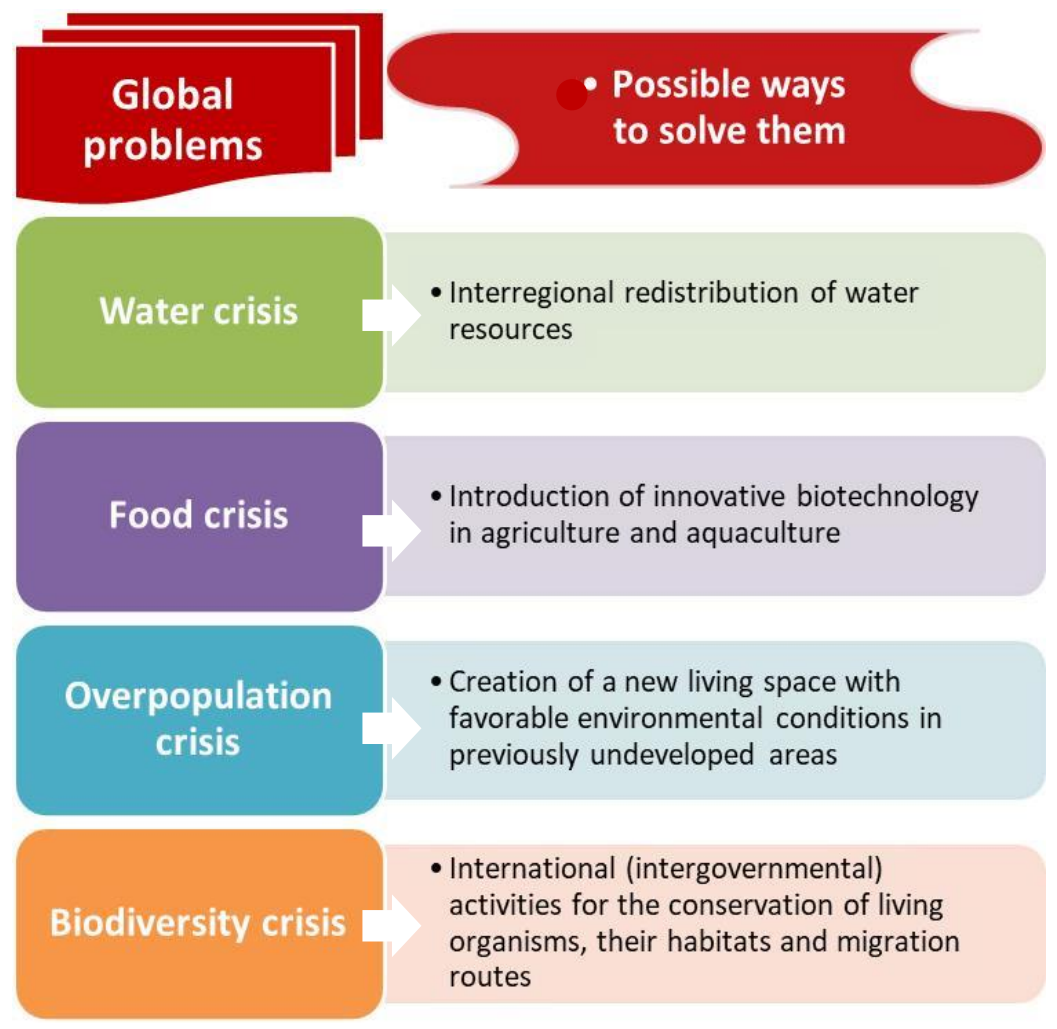

Fig. 6. Real solutions to global crises based on a creative paradigm (Suzdaleva A.L.www.ntsyst.ru).

Environmental globalistics is called upon to solve these problems - a new interdisciplinary area of interconnected scientific, theoretical and applied activities, the purpose of which is to create mechanisms for managing the state of the environment on a planetary scale [9].

World crises are caused by the global technogenesis of the biosphere. Manifestations of the process of technogenesis are very diverse. They include various changes in the properties and structure of the atmosphere, hydrosphere and lithosphere, as well as near-earth space [10]. Each of them individually can be designated as an aspect of technogenesis. The methods of working with their various categories vary considerably. For this reason, it is advisable to single out several main areas of environmental globalistics [11], each of which includes the management of one of the aspects of environmental technogenesis (Table 2).

Table 2. The main areas of environmental globalistics.

\begin{tabular}{|l|l|l|}
\hline \multicolumn{1}{|c|}{ Areas } & \multicolumn{1}{|c|}{ Research subject and field of } \\
activity & \multicolumn{1}{c|}{ Main goal } \\
\hline $\begin{array}{l}\text { General } \\
\text { environmental } \\
\text { globalistics }\end{array}$ & $\begin{array}{l}\text { Study of the patterns of } \\
\text { development of global } \\
\text { technogenesis and the development } \\
\text { of programs to coordinate the } \\
\text { development of all areas of } \\
\text { environmental globalistics }\end{array}$ & $\begin{array}{l}\text { Development of scientific } \\
\text { foundations for creating a } \\
\text { controlled biotechnosphere }\end{array}$ \\
\hline $\begin{array}{l}\text { Resource } \\
\text { environmental } \\
\text { globalistics }\end{array}$ & $\begin{array}{l}\text { Assessment and forecast of the } \\
\text { global environmental consequences } \\
\text { of the use of the Earth's resources }\end{array}$ & $\begin{array}{l}\text { Development of actions to prevent } \\
\text { the depletion of resources and the } \\
\text { development of global crises } \\
\text { caused by them }\end{array}$ \\
\hline
\end{tabular}




\begin{tabular}{|l|l|l|}
\hline $\begin{array}{l}\text { Industrial and } \\
\text { economic } \\
\text { environmental } \\
\text { globalistics }\end{array}$ & $\begin{array}{l}\text { Crisis changes in the environment } \\
\text { in the process of development of the } \\
\text { sphere of world production and } \\
\text { consumption }\end{array}$ & $\begin{array}{l}\text { Development of practical } \\
\text { measures to comply with the UN } \\
\text { principle of sustainable } \\
\text { development }\end{array}$ \\
\hline $\begin{array}{l}\text { Medical } \\
\text { environmental } \\
\text { globalistics }\end{array}$ & $\begin{array}{l}\text { Study of the impact of global } \\
\text { technogenesis on human health and } \\
\text { the emergence of new dangerous } \\
\text { diseases in these environmental } \\
\text { conditions }\end{array}$ & $\begin{array}{l}\text { Prevention of an increase in the } \\
\text { incidence of diseases directly or } \\
\text { indirectly caused by global } \\
\text { technogenesis }\end{array}$ \\
\hline $\begin{array}{l}\text { Demographic } \\
\text { environmental } \\
\text { globalistics }\end{array}$ & $\begin{array}{l}\text { Study of the influence of global } \\
\text { technogenesis on the growth of the } \\
\text { world's population and the nature of } \\
\text { its distribution }\end{array}$ & $\begin{array}{l}\text { Development of measures to } \\
\text { achieve a balance between the } \\
\text { growth of the world's population } \\
\text { and the amount of resources } \\
\text { necessary to ensure the normal } \\
\text { functioning of people }\end{array}$ \\
\hline $\begin{array}{l}\text { Invasive ecological } \\
\text { globalistics }\end{array}$ & $\begin{array}{l}\text { Study of the processes of dispersal } \\
\text { of organisms in the process of } \\
\text { global technogenesis }\end{array}$ & $\begin{array}{l}\text { Preventing the spread of unwanted } \\
\text { organisms }\end{array}$ \\
\hline $\begin{array}{l}\text { Geopolitical } \\
\text { environmental } \\
\text { globalistics }\end{array}$ & $\begin{array}{l}\text { Study of the impact of the } \\
\text { geopolitical situation on global } \\
\text { environmental processes }\end{array}$ & $\begin{array}{l}\text { Forecast of global environmental } \\
\text { consequences in case of a possible } \\
\text { change in the geopolitical } \\
\text { situation }\end{array}$ \\
\hline
\end{tabular}

Despite the difference in the goals of individual areas of environmental globalistics, the development of each of them can be carried out only on the basis of a creative paradigm, i.e. the purposeful creation of a single controllable natural and technical system on the planet - a controlled biotechnosphere. It is obvious that its creation cannot occur as a one-time transformation of the environment on a global scale. Such an attempt could be disastrous. The implementation of the creative paradigm can only be carried out according to the bottomup approach $[12,2]$. It implies the creation of a large number of separate objects intended for subsequent integration into a single system. At the first stage, each of these objects performs tasks on a local scale. At the next stage, the coordinated work of several objects makes it possible to manage the development of the situation on a regional scale. An example is the solution to the world water crisis [13]. At the first stage, the most acute problems can be solved by creating separate routes for water resource logistics. Each of them consists of hydraulic structures that transport water from one region to another (pipelines or canals) and storage tanks (reservoirs), ensuring the sustainability of water supply. Such a waterway can become the basis for creating a controlled natural and technical system. At the next stage, it is possible to combine several such routes into a water-resource logistics network, for example, by connecting their water storage tanks. This opens up opportunities for managing water resources and controlling the ecological situation in a large part of the continent due to the creation of a manageable natural-technical system of a larger scale within this territory. The ultimate goal of the development of this area of ecological globalistics is to create a resource management system for the entire hydrosphere on the basis of the coordinated functioning of the hierarchy of controlled natural and technical systems in its individual areas. Only this approach to solving the problem of the global crisis can give real results.

Similarly, on the basis of a creative paradigm, threats from other world crises generated by the global technogenesis of the environment can be eliminated. For example, the demographic crisis is already being solved in a number of countries through the construction of artificial land plots and islands $[14,15]$. But a sustainable positive effect of this activity can be achieved through coordination of efforts, the basis for which is created by scientific research and the development of projects in the field of ecological globalistics.

In conclusion, it should be noted that the longer the priority of the restrictive-prohibitive paradigm is maintained, the more difficult it will be in the future to take real actions to prevent 
the further development of global negative trends. An unbiased discussion of the need to adopt a creative paradigm can influence the current situation. It should be emphasized that this does not in any way imply a complete rejection of prohibitive-restrictive measures. The question only concerns their significance as a basic methodology.

Conclusions about the prospects of both paradigms should be based not on the established stereotypes of "ecological thinking", but on a comparison of the predicted results of the proposed solutions to the problem. At the same time, it is important to remember that any human activity, including those carried out to solve environmental problems, is always associated with some kind of negative impact. But their assessment should be based not on determining the possible environmental damage, but on comparing it with the damage that will be caused to the environment in the foreseeable future if active actions in this area are abandoned. Thus, the construction of artificial land plots is inevitably accompanied by the destruction of a part of the marine ecosystem [16]. But the overpopulation of coastal areas and the difficulty of developing infrastructure on them often causes more significant environmental damage as a result of pollution of coastal waters. In addition, damage to the marine ecosystem during the creation of artificial land plots can be largely compensated for by creating artificial reefs around them and the construction of hydraulic structures that protect the organisms of coastal waters from the impact of surf during storms [17-20].

\section{Conclusion}

1. The global technogenesis of the environment necessitates the development of ecological globalistics - a new interdisciplinary field of activity, including scientific and theoretical research and the development of actions to preserve and improve the state of the environment on a global scale.

2. The outdated restrictive-prohibitive paradigm of environmental protection is an obstacle to the implementation of innovative solutions in practice, allowing not to limit negative impacts, but also to manage the environmental situation.

3. Refusal to switch to a creative paradigm when solving global environmental problems will inevitably lead to further deterioration of the environmental situation and deepening of the complex of world crises caused by the lack of vital resources.

\section{References}

1. V.G. Udaltsov, Vestnik TvGU. Ser. Filosofiya 4, 5-12 (2013)

2. A.L. Suzdaleva, S.V. Goryunova, Biosphere 7(4), 429-449 (2015)

3. Yu.I. Romanov, I.G. Shestakova, Ekonomika i ekologicheskij menedzhment 2, 407-415 (2012)

4. Yu.G. Shpakovskii, Courier of Kutafin Moscow State Law University 1(17), 38-63 (2016)

5. Yu.L. Vorobiev, Problemy analiza riska 8(2), 8-13 (2011)

6. Arefiev, N., Mikhalev, M., Zotov, D., Zotov, K., et al., Procedia Engineering. 2015. 117(1). Pp. 32-38. DOI:10.1016/j.proeng.2015.08.120.

7. Baiburin, A.K., Rybakov, M.M., Vatin, N.I. Magazine of Civil Engineering. 2019. 85(1). Pp. 3-14. DOI:10.18720/MCE.85.1.

8. I. Ilić, P. Hafner, Facta universitatis. Series: Economics and Organization 12(2), 109120 (2015)

9. A.L. Suzdaleva, S.V. Goryunova, Biotechnosphere: ecology and life safety (Moscow City University, Moscow, 2017) 
10. A.L. Suzdaleva, Inzheneraya Geologiya, Gidrogeologiya, Geokriologiya 1, 6-11 (2020)

11. A.L. Suzdaleva, Safety in Technosphere 6(1), 10-18 (2017)

12. A.L. Suzdaleva, Estestvennye i tekhnicheskie nauki 9(135), 67-70 (2019)

13. E.D.G. Fraser, A.J. Dougill, W.E. Mabee, M. Reed, P. McAlpine, J. Environ. Manage 78(2), 114-127 (2006)

14. A.L. Suzdaleva, World Economy and International Relation 61(11), 5-12 (2017)

15. S.Y. Chee, A.G. Othman, Y.K. Sim, A.N.M. Adam, L.B. Firth, Global Ecology and Conservation 12, 80-95 (2017)

16. A.L. Suzdaleva, Gidrotekhnicheskoe stroitel'stvo 5, 43-49 (2020)

17. A.A. Givi, S. Karimi, M. Sadat, M. Zoghi, S. Karimi, N. Foroughi, B. Malekmohamadi, International Journal of Environmental Monitoring and Analysis 3(3), 139-146 (2015)

18. M. Baine, Ocean Coast. Manag. 44(3-4), 241-259 (2001)

19. K.A. Dafforn, T.M. Glasby, L. Airoldi, N.K. Rivero, M. Mayer-Pinto, E.L. Johnston, Front. Ecol. Environ. 13(2), 82-90 (2015)

20. M. Mayer-Pinto, E.L. Johnston, A.B. Bugnot, T.M. Glasby, L. Airoldi, A. Mitchell, K.A. Dafforn, J. Environ. Manag. 189, 109-114 (2017) 